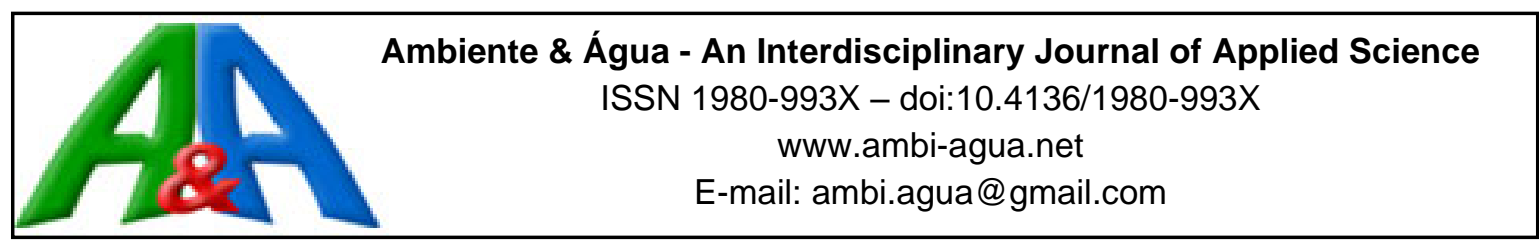

\title{
Potentialities of water charge in the management of Brazilian water resources
}

\author{
ARTICLES doi:10.4136/ambi-agua.2531 \\ Received: 07 Feb. 2020; Accepted: 22 Jun. 2020 \\ Fernanda Neves Ferreira ${ }^{1(D)}$; Hebe Morganne Campos Ribeiro ${ }^{2 *(D)}$; \\ Vítor Abner Borges Dutra ${ }^{3}$ [D \\ ${ }^{1}$ Instituto de Ciências Jurídicas. Universidade Federal do Pará (UFPA), Rua Augusto Corrêa, ${ }^{\circ}{ }^{1}$, \\ CEP: 66075-110, Belém, Pará, Brazil. E-mail: nanda_fnf@yahoo.com.br \\ ${ }^{2}$ Departamento de Engenharia Ambiental. Universidade do Estado do Pará (UEPA), Travessa Enéas Pinheiro, \\ no 2626, CEP: 66095-015, Belém, PA, Brazil. \\ ${ }^{3}$ Instituto de Geociências. Universidade Federal do Pará (UFPA), Rua Augusto Corrêa, n 1 , \\ CEP: 66075-110, Belém, Pará, Brazil. E-mail: vitor.druidaum@gmail.com \\ *Corresponding author. E-mail: hebemcr@gmail.com
}

\begin{abstract}
We investigated the application of economic instruments in the management of Brazilian water resources as mechanisms to stimulate the rational use of water and to recognise its economic value. We analysed water-charge scenarios at the national and international levels as a methodology to provide an economic estimate of environmental services related to water resources. Through bibliographical and documentary research, we identified the economic instruments applied to Brazilian water-resource management, describing the methodologies and values used Brazilian water charges and in some member states of the Organization for Economic Cooperation and Development. We identified how economic valuation methods of environmental resources could contribute to the improvement of water charges, considering the environmental services offered by a healthy river basin. In the Brazilian and the international scenarios, water charge methodologies include the volumetry of abstracted or consumed water, associating some elements that indicate the pollution level. The prices per cubic meter of water are still very low in all the scenarios. Environmental valuation techniques can be an essential tool for rethinking the methodologies and costs applied in water charges, increasing the potential of water's rational use through economic instruments.
\end{abstract}

Keywords: economic instruments, environmental valuation, water availability.

\section{Potencialidades da cobrança pelo uso da água na gestão hídrica Brasileira}

\section{RESUMO}

Investigou-se a aplicação de instrumentos econômicos na gestão de recursos hídricos brasileiros como mecanismo para estimular o uso racional da água e reconhecer seu valor econômico. Analisou-se a cobrança pelo uso da água nas experiências nacionais e internacionais, com o objetivo de verificar a aplicação da valoração econômica dos recursos naturais como uma metodologia para fornecer uma estimativa econômica dos serviços ambientais relacionados aos recursos hídricos. Por meio de uma pesquisa bibliográfica e documental, identificaram-se os instrumentos econômicos aplicados à gestão de recursos 
hídricos brasileiros, descrevendo as metodologias e valores utilizados na cobrança de água no Brasil e em alguns estados membros da Organização para Cooperação e Desenvolvimento Econômico. Identificou-se como os métodos de avaliação econômica dos recursos ambientais poderiam contribuir para a melhoria da cobrança pelo uso de água, considerando os serviços ambientais oferecidos por uma bacia hidrográfica saudável. Nas experiências brasileiras e internacionais, as metodologias de cobrança pelo uso de água incluem a volumetria da água captada ou consumida, associando alguns elementos que indicam o nível de poluição. Os preços do metro cúbico de água ainda são muito baixos em todas as experiências. As técnicas de avaliação ambiental podem ser uma ferramenta essencial para repensar as metodologias e os custos aplicados na cobrança pelo uso de água, aumentando o potencial de uso racional da água por meio de instrumentos econômicos.

Palavras-chave: disponibilidade hídrica, instrumentos econômicos, valoração ambiental.

\section{INTRODUCTION}

There are many ways to promote the equitable, efficient and sustainable use of water. Command and control instruments are a strategy used by many countries (Arimura et al., 2008), and this approach is considered the first generation of environmental policy regulations (Gómez-Baggethun and Muradian, 2015). However, there are criticisms regarding the efficiency of that approach when it is compared to the use of economic instruments (Vatn, 2015; Bergquist et al., 2013; Rogers et al., 2002). Economic approaches are an alternative to the command and control approaches. In water-resource management, the use of economic strategies aims to internalise the costs of economic activity that are not covered by the market (Liao, 2018). Such costs are supported by society, as the case of pollution (Nusdeo, 2006). However, the use of economic instruments is seen as a complement to the command and control approach (Nascimento et al., 2010), and this interaction is described as a "mixed policy" (Begossi et al., 2011).

The international community recognised the need for global coordination of water challenges in 1977 at the United Nations Conference on Water at Mar Del Plata, Argentina, which is considered a founding part of the global water agenda (Schmidt and Matthews, 2017). Later, many declarations and programs about the problems of water availability were adopted after conferences promoted by the United Nations - UN. The Dublin Conference about Water Resources and Sustainable Development in January 1992 explicitly recognised water as an economic good for the first time in the international community through its principles (Rogers et al., 2002).

France was the first country to introduce a water charge as an instrument of water management, aiming to encourage the rational use of water and indicate its economic value, as well as to allocate financial resources in the hydrographic basin in a participatory way (Demajorovic et al., 2015). The French water management structure was suggested as a template for other countries, referring to the European Framework Directive 2000/60/EC (Berreta et al., 2012). The French structure inspired Brazilian water-resource management, which is regulated by Law no. 9,433, of January 8, 1997, named the "National Water Resources Policy Law" - NWRP (Johnsson, 2001; Theodoro et al., 2016; Brasil, 1997). Moreover, water in Brazil has a public domain property which can be at the federal or state level, according to Article 20, Item III and Article 26, Item I, of the Federal Constitution, respectively (Milaré, 2011).

For the Organization for Economic Cooperation and Development (OECD), the price level and the methodologies of water charges try to reflect the costs and externalities related to the domestic and industrial use of water by the abstraction and pollution (OCDE, 2010). According to The Economics of Ecosystems and Biodiversity (TEEB), before charging for access to and use of environmental services, two steps are first necessary: identify and evaluate such services, 
then estimate and demonstrate their values by appropriate methods (TEEB, 2010). These steps contribute to avoiding the non-valuation or the undervaluation of environmental services provided by a healthy river basin.

This research describes the economic instruments applied in Brazilian water-resource management. However, we focus on the water charge in the national context, and we demonstrate the water charge panorama in other countries aiming to investigate the methods of its application. This initial investigation aims to verify whether the practices of water charge have considered the perspective of economic valuation of water resources as a way to promote their sustainable use through price or methodology.

\section{MATERIAL AND METHODS}

To investigate the environmental valuation perspective in Brazilian water charge, we built a conceptual framework regarding the economic instruments applied to Brazilian waterresource management, focusing on water charge. We also investigated the water charge panorama in some foreign countries to explore the application of an environmental valuation perspective. This is an exploratory and descriptive analysis that was built through bibliographical and documentary research (Prodanov and Freitas, 2013; Medeiros and Tomasi, 2016).

We analysed Brazilian federal legislation on water-resource management to identify the variables to compound the water-charge methodology. For the international panorama of water charge, we chose some OECD member countries, because this institution has developed studies on water pricing practices since 1999 (OECD, 2010). We also chose country scenarios that had a more detailed description of water charge in the document "Pricing water resources and water and sanitation services" (OECD, 2010). Also, we preferred countries with available data in the "Database on policy instruments for the environment" (OECD, 2016). Thus, we chose Germany, Australia, Belgium, Canada and Poland.

Through bibliographic research, we identified the environmental services provided by water resources to demonstrate their economic values. We then investigated the environmental valuation methods, which are more suitable for the economic estimation of environmental services of water resources, aiming to contribute to the improvement of water charges.

\section{RESULTS AND DISCUSSION}

For better understanding, we organised the results and discussion in subsections. In the first subsection, we analysed the economic instruments applied in Brazilian water-resource management. We then demonstrated the water charge scenario in Brazil and other countries aiming to investigate the methods of its application. In the last subsection, we analysed the perspective of the economic valuation of the environmental resources as a way to promote the sustainable use of water resources in water-charge prices and methodologies.

\subsection{Economic instruments in Brazilian water resources management}

A different strategy is the use of economic instruments. This approach acts directly on the price of a resource, changing its cost and leading to cost-effective allocation (Nusdeo, 2006; Sterner and Robinson, 2018). By this approach, the internalisation of environmental costs considers the cost structures of each economic agent (Motta, 2000). In Brazil, the water charge is classified as a public price, because a private user is authorised by a granting to explore a public good and to pay a price that is negotiated between the state and the stakeholders (Milaré, 2011). In this context, the state acts as a private entity; it is under private law regime, without the coercive character (Harada, 2016). But the income must be applied in the river basin, and this can generate benefits to the community all around, not only to the granted water user. 
In Brazilian water-resource management, there is also the fee, which is different from the water charge. The fee can be related to two different contexts: the police fee and the service fee, according to Article 145, Item II, of the Federal Constitution (Harada, 2016; Paulsen, 2012). The first represents an intervention of the public power in the property or freedom of the person to achieve general well-being. The second is a payment for the supply or availability of a specific and divisible public service. In the case of water resources, there is the inspection fee for the use of water resources in the Federal District, Pará State and Paraná State (ANA, 2016). Two other instruments related to water-resource management are the tariff and the Financial Compensation for the Exploration of Water Resources (FCEWR). The tariffs follow the legal regime of private law. They can be applied when concessionary companies provide activities that are non-essential and not inherent to the State (Harada, 2016). There is the tariff for the supply of raw water in Bahia State and Ceará State (ANA, 2016).

The FCEWR is established by the Federal Constitution, in the final part of $\S 1^{\circ}$, in Article 20 (Brasil, 1988). The FCEWR is a public price because the income comes from the direct exploration of a public good. Also, the FCEWR is an obligation only for the concessionaire company that voluntarily adheres to a contract in which the FCEWR is foreseen (Leite, 2009). The FCEWR is equivalent to $7 \%$ of the amount of energy generated by a hydroelectric plant. The income is divided between the Federal Government (10\%) and the states and municipalities ( $45 \%$ each) that suffered the negative impacts of the installation and operation of the plant. The FCEWR is a way to compensate the states and municipalities financially (Gomes et al., 2017; Brasil, 1998). In Pará State, the FCEWR is related to the hydroelectric plants of Tucuruí, Belo Monte and Teles Pires (ANEEL, 2017).

The payment for environmental services (PES) is relatively new in Brazilian waterresource management. This market mechanism is based on the "provider-receiver" principle. The PES involves a voluntary transaction between one or more users of one or more environmental services and the providers who are capable of guaranteeing the provision (Andrade and Fasiaben, 2009). Five elements characterise the PES: willingness in the transaction; a well-defined environmental service to be "bought"; the existence of at least one buyer; the participation of at least one provider; and a guarantee condition of the service provision (Santos et al., 2017). In Brazil, the first PES experience was in Extrema city, in Minas Gerais State, through the "Conservative Water Program". The ICMS-Ecological tax financed the program. Through this PES strategy, rural landowners received a financial incentive for the practices in reducing sedimentation and erosion, aiming to improve water quality and supply. Regarding the payment methodology, there was a fixed price that changed according to the percentage of erosion avoided, for example, $\mathrm{R} \$ 50.00$ (fifty reais) per hectare if the reduction was from 25\% to 50\% (Young and Bakker, 2015).

As water resources have a public domain, there is a low willingness to pay for the environmental services provided by the water basin. Also, water resources are a non-exclusive and rival good. Public authorities are required to create policies and programs in favour of supply to stimulate environmental service providers and to improve the market-based instruments (Santos et al., 2017).

The last economic instrument analysed was tradable permits and licenses. This strategy transfers to economic agents the decision regarding sale transactions involving the emission levels not yet reached; but it is the Public Authority that establishes the emission levels based on levels of ecological security. This requires full control of historical emissions data, as well as the establishment of transparent rules and effective monitoring of data (GVCES, 2017). For example, we have the quota negotiation of environmental legal reserve in Article 44 of Law no. 12.651 / 2012, which established the New Forest Code (Santos et al., 2017). As water has a public domain, sales of water grants are unconstitutional. It would be necessary to adapt this mechanism, enabling the State participation as an intermediary and as an authoriser of this 
transaction. This adaptation would secure the water public domain, creating a kind of controlled market (Lanna, 2002).

\subsection{Water charge panorama: Brazilian and international scenarios}

In Brazil, the water charge is an instrument of water management established in Article 5, Item IV of the NWRP Law. Articles 19 to 22 describe the general guidelines regarding the objectives, incidence, parameters for value and methodology setting of water charge. This instrument aims to recognise water as an economic good and indicate its real value. Also, the water charge seeks to encourage rational water use as well as to get incomes to cover the costs of the programs and interventions foreseen in the water-resources plan (Brasil, 1997). The water charge is based on the principle of user-payer, because a price is used to encourage rational and efficient use, avoiding scarcity and exploitation at zero cost (Milaré, 2011). The payment is justified by the economic exploitation in large quantities of a scarce environmental resource (Farias and Damacena, 2017), and it is expected that the economic agent will change his behaviour to minimise negative externalities (Godoy, 2011).

The water charge also emphasises participatory political governance. For example, it reinforces the democratic participation of stakeholders in the decision-making process about water stress points and sustainable measures (Bolson and Haonat, 2016). The NWRP Law made this possible because it created a decentralised management structure: the National System of Water Resources Management (SINGREH). Therefore, knowing SINGREH composition is vital to understand the water charge because the SINGREH components are responsible for its elaboration (Millan, 2008). In Table 1, we show the structure and the competencies of each SINGREH member related to the water charge.

Table 1. Members of SINGREH and description of some of their competencies related to water charge.

\begin{tabular}{|c|c|c|}
\hline Member & Identification & Some competencies related to the water charge \\
\hline $\begin{array}{l}\text { National Council of } \\
\text { Water Resources } \\
\text { (NCWR) }\end{array}$ & $\begin{array}{l}\text { SINGREH Higher } \\
\text { Collegiate Body }\end{array}$ & Establish general criteria for water charge in Federal scope. \\
\hline $\begin{array}{l}\text { National Water } \\
\text { Agency (NWA) }\end{array}$ & $\begin{array}{l}\text { Federal authority under a } \\
\text { special regime }\end{array}$ & $\begin{array}{l}\text { Implement, in articulation with the HBC's, the water charge at Union } \\
\text { domain, as well as to collect, distribute and apply the incomes of water } \\
\text { charge. }\end{array}$ \\
\hline $\begin{array}{l}\text { Secretariat of } \\
\text { Water Resources } \\
\text { (SWR) }\end{array}$ & $\begin{array}{l}\text { NCWR Executive } \\
\text { Secretariat }\end{array}$ & Provide administrative, technical and financial support to the NCWR. \\
\hline $\begin{array}{l}\text { State Council for } \\
\text { Water Resources } \\
\quad(\text { SCWR })\end{array}$ & $\begin{array}{l}\text { State supreme Collegiate } \\
\text { body }\end{array}$ & $\begin{array}{l}\text { Define the values of water charge at State domain based on the } \\
\text { mechanisms and values suggested by HBC. }\end{array}$ \\
\hline $\begin{array}{l}\text { State Management } \\
\text { Bodies }\end{array}$ & $\begin{array}{l}\text { Central body and } \\
\text { coordinator of the State } \\
\text { System of Resource } \\
\text { Management }\end{array}$ & $\begin{array}{l}\text { Implement, in articulation with the HBC's, the water charge at State } \\
\text { domain, as well as elaborate technical studies to subsidise the } \\
\text { respective SCWR in the definition of water charge values. }\end{array}$ \\
\hline $\begin{array}{l}\text { Hydrographic } \\
\text { Basin Committee } \\
\quad(\mathrm{HBC})\end{array}$ & Body of the first instance & Suggest the mechanisms and values of water charge. \\
\hline Basin Agencies & HBC Executive Arm & $\begin{array}{l}\text { Perform, through delegation of the grantor, the water charge; analyse } \\
\text { and issue opinions on the projects and works to be financed with the } \\
\text { water-charge incomes; monitor the financial management of funds } \\
\text { raised through water charge; propose to the respective HBC the plan } \\
\text { of application of the water charge income. }\end{array}$ \\
\hline
\end{tabular}

Source: ANA (2014) and Braga et al. (2008), with adaptations. 
As a rule, the granted users must pay the water charge. Granting the right to use water resources is a mandatory instrument to the water uses that change the regime, the quantity or quality of surface water or groundwater. The uses are the capitation, derivation and extraction of water for final consumption or as a productive process input, as well as to dump waste for dilution, transport or serve as final disposal destination (Brasil, 1997). The water uses include hydroelectric potential, public supply, aquaculture and recreation activities. The water charge will vary proportionally to the individual volumes demanded, the price established by the Water Resources Councils and the weighting coefficients instituted according to the needs of each river basin (Santin and Goellner, 2013).

In Brazil, there are experiences of water charge in some States: Ceará, São Paulo, Rio de Janeiro, Minas Gerais, Paraná, Paraíba, Maranhão and Bahia. At interstate basins, there is water charge in the Paraíba do Sul Basin; the Piracicaba Basin, Capiravi and Jundiaí; Basin of the São Francisco River; the Rio Doce Basin; the Rio Verde Grande Basin; and Basin of the Paranaíba River (ANA, 2018). The methodology for water charge in federal river basins follows the same formula: " $\mathrm{C}=\mathrm{Q} \times \mathrm{P} \times \mathrm{K}$ ", where $\mathrm{C}$ is the total of water charge, $\mathrm{Q}$ is the volume, $\mathrm{P}$ is the unit price and $\mathrm{K}$ is a weighting coefficient which varies according to the needs of the river basin (ANA, 2014). Table 2 describes the peculiarities of each weighting coefficient per federal basin.

Table 2. Variables considered as weighting coefficient by type of intervention in the water-charge methodologies at interstate rivers.

\begin{tabular}{|c|c|c|c|c|c|}
\hline \multirow{2}{*}{$\begin{array}{c}\text { Type of } \\
\text { Intervention }\end{array}$} & \multicolumn{5}{|c|}{ Variables considered in the " $K$ " weighting coefficient per federal basin } \\
\hline & $\begin{array}{c}\text { Paraíba do Sul } \\
\qquad(2002)\end{array}$ & $\begin{array}{c}\text { PCJ } \\
(2006)\end{array}$ & $\begin{array}{c}\text { São Francisco } \\
(2010)\end{array}$ & $\begin{array}{c}\text { Doce } \\
(2011)\end{array}$ & $\begin{array}{c}\text { Verde Grande } \\
(2017)\end{array}$ \\
\hline Capitation & $\begin{array}{l}\text { Type of use, } \\
\text { effective use, the } \\
\text { efficiency of the } \\
\text { technology applied } \\
\text { for the use, and the } \\
\text { water body class }\end{array}$ & $\begin{array}{l}\text { Type of use, } \\
\text { effective use, the } \\
\text { effectiveness of the } \\
\text { technology applied } \\
\text { for the use, and the } \\
\text { water body class }\end{array}$ & $\begin{array}{l}\text { The efficiency of } \\
\text { the technology } \\
\text { applied for the } \\
\text { use, and the } \\
\text { water body class }\end{array}$ & $\begin{array}{l}\text { Type of use, } \\
\text { effective use, the } \\
\text { effectiveness of the } \\
\text { technology applied } \\
\text { for the use, and the } \\
\text { water body class }\end{array}$ & $\begin{array}{l}\text { Nature of use } \\
\text { and/or good } \\
\text { practices, water } \\
\text { body class and } \\
\text { management } \\
\text { efficiency }\end{array}$ \\
\hline Consumption & Purpose of use & $\begin{array}{l}\text { The technology } \\
\text { applied for efficient } \\
\text { consumption }\end{array}$ & Purpose of use & $\begin{array}{l}\text { There is no } \\
\text { weighting }\end{array}$ & $\begin{array}{l}\text { Purpose of use and } \\
\text { nature of use } \\
\text { and/or good } \\
\text { practices }\end{array}$ \\
\hline Release & $\begin{array}{l}\text { Organic load } \\
\text { released }\end{array}$ & $\begin{array}{l}\text { Organic load } \\
\text { released and water } \\
\text { body class }\end{array}$ & $\begin{array}{c}\text { Organic load } \\
\text { released and } \\
\text { water body class }\end{array}$ & $\begin{array}{l}\text { Organic load } \\
\text { released }\end{array}$ & $\begin{array}{l}\text { Organic load } \\
\text { released }\end{array}$ \\
\hline Transposition & $\begin{array}{c}15 \% \text { income of } \mathrm{BH} \\
\text { Guandu }\end{array}$ & $\begin{array}{l}\text { Quality of transposed } \\
\text { water }\end{array}$ & Priority of use & $\begin{array}{c}\text { Organic load } \\
\text { released, } \\
\text { Quality of transposed } \\
\text { water }\end{array}$ & None \\
\hline
\end{tabular}

Source: ANA (2014) and CBH-Verde Grande (2015), with adaptations.

According to the NWA, the unit prices in each interstate basin are low. They are not enough to recompense all the demands foreseen in the water-resource plans and to stimulate the rational use of water (ANA, 2014). The prices in each interstate basin are described in Table 3. Note that the PCJ and Rio Doce Basins are the only ones to adopt the progressivity of prices (Finkler et al., 2015).

The prices in the Paraíba do Sul, São Francisco and Verde Grande Federal Basins are the same. Although the SINGREH members endeavoured to implement the NWRP, the adoption of similar methodologies and prices may represent disagreement with the general guideline of action that demands "the adequacy of water resources management to the physical, biotic, demographic, economic, social and cultural diversities of the several regions of the country" (Article 3, Item II, of NWRP Law) (Brasil, 1997). For example, the São Francisco River Basin 
has peculiar characteristics, such as its great extension (that covers $7.5 \%$ of the country, passing through the states of Minas Gerais, Bahia, Goiás, Federal District, Pernambuco, Alagoas and Sergipe). Also, there is a demand for different types of water use, such as power generation, navigation, irrigation, fishing and effluent dilution. This scenario indicates that it is convenient to adopt progressive unit prices because the actual incomes are not enough to finance all the measures, programs and projects to improve the basin (Vera et al., 2017).

Table 3. Unit prices applied in interstate river basins.

\begin{tabular}{lccccc}
\hline \multirow{2}{*}{ Type of water use } & \multicolumn{5}{c}{ Hydrographic Basin } \\
\cline { 2 - 6 } & Paraíba do Sul & PCJ & São Francisco & Doce & Verde Grande \\
\hline Capitation $\left(\mathrm{R} \$ / \mathrm{m}^{3}\right)$ & 0,01 & $0,0100-0,0127$ & 0,01 & $0,018-0,030$ & 0,01 \\
Consumption $\left(\mathrm{R} \$ / \mathrm{m}^{3}\right)$ & 0,02 & $0,0200-0,0255$ & 0,02 & - & 0,02 \\
Release $(\mathrm{R} \$ / \mathrm{kg} \mathrm{DBO})$ & 0,07 & $0,1000-0,1274$ & 0,07 & $0,1000-0,160$ & 0,07 \\
Transposition $\left(\mathrm{R} \$ / \mathrm{m}^{3}\right)$ & - & $0,0150-0,0191$ & - & $0,022-0,040$ & - \\
\hline
\end{tabular}

Source: Finkler et al. (2015) and CBH-Verde Grande (2015), with adaptations.

The water charge has undergone evolutions, being improved with each revision of methodology and price in the interstate basins. For example, the method of water charge in the PCJ River Basin has greater detail due to the learning acquired with the observation of the predecessor's experiences (Finkler et al., 2015). A very representative example is the recent institution of water charge in the Paranaíba River Hydrographic Basin. The Paranaíba HBC has adopted progressive price and a methodology that considers several aspects such as water framework, nature and/or good practices of the use, the purpose of the use, the index of losses of water to stimulate the efficiency, the released volume of organic load, and others $(\mathrm{CBH}-$ Paranaíba, 2016).

According to OECD studies, water abstraction charging in member countries has varied methodologies (OECD, 2010). It varies by country, by user sector, and it may be associated with water granting regime, varying according to volume consumed or other criteria. The charge seeks to correct the inefficient use of water by inducing behavioural change and internalising the negative externalities of economic activities, as well as generating incomes for investments that benefit society (OECD, 2017). In most cases, the water charge aims to raise incomes to cover water-management costs or the costs of activities to protect the river basins (OECD, 2010). In Table 4, we describe the water charge panorama in some OECD member countries.

However, the OECD notes that the prices are relatively low and that there is a tendency to be higher when it comes to the use of groundwater, as shown in Table 5 (OECD, 2010). The aquifers work as freshwater reservoirs. Therefore, the abstraction increase of groundwater may justify the higher prices of water charge for the use of these sources in the OECD countries (Foster et al., 2013).

The prices per cubic meter vary from very low to much higher values, e.g., the prices for the quantity of abstracted surface water in Poland and the prices for quantity and quality of pollution in the region of Flanders in Belgium. This same disparity between the prices in each OECD country was noted by Godoy (2011). Mattheiß et al. (2010), in a complementary study to the OECD surveys, indicated the difficulty in obtaining information about the total incomes raised and their application. This is an obstacle to evaluating the effectiveness of the economic instruments regarding their capacity to cover all the costs of integrated water-resource management. 
Table 4. A short overview of water charge in some OECD member countries.

\begin{tabular}{|c|c|}
\hline Member country & Overview of water use charges \\
\hline German & $\begin{array}{l}\text { The water charge for abstraction was instituted to reduce consumption and increase incomes for investment in environmental protection measures, such as protection } \\
\text { of groundwater and surface water, reforestation, soil protection and decontamination. Of the } 16 \text { federal states, } 11 \text { have a water charge for abstraction. }\end{array}$ \\
\hline Australia & $\begin{array}{l}\text { The water charge for abstraction is composed of a two-part methodology: a fixed price and a volumetric price. The latter is the sum of the rate of water abstraction } \\
\text { and the price of use which will fall on the quantity of abstracted water. In the water charge for pollution, the methodology is based on volume, pollution level and } \\
\text { location. Seventeen types of pollutants are charged. }\end{array}$ \\
\hline Belgium & $\begin{array}{l}\text { In the water charge for groundwater abstraction, in Flanders, the price per cubic meter increases with the total amount of groundwater pumped, and varies according } \\
\text { to the aquifer exploited and the pressure in the groundwater. For surface waters, there is a decreasing block system to charge for the captation. But the water charges } \\
\text { for surface water are lower than groundwater. There is also a charge for pollution based on measured concentration or conversion coefficients for organic matter and } \\
\text { suspended solids, heavy metals, nutrients (Nitrogen and Phosphorus). }\end{array}$ \\
\hline Canada & $\begin{array}{l}\text { The water charge for abstraction varies according to each province based on the capacity of abstraction. It varies by volume and by different characteristics in } \\
\text { methodology by province. There is a charge for the release of industrial effluents that varies by quantity released and by other criteria established by the province. }\end{array}$ \\
\hline Poland & $\begin{array}{l}\text { The water charge for abstraction varies by type of use, and the methodology varies by type of source and location. The water charge for pollution is based on the } \\
\text { volume, type of pollutant, industrial sector, and receiving water body. }\end{array}$ \\
\hline
\end{tabular}

Source: OECD (2010), with adaptations.

Table 5. Water charge by sector and origin in some OECD member countries.

\begin{tabular}{|c|c|c|c|c|c|c|}
\hline \multirow{2}{*}{ Country } & \multirow{2}{*}{ Name of the instrument } & \multirow{2}{*}{ Description of charge basis } & \multicolumn{4}{|c|}{ Prices by use type $\left(€ \mathbf{m}^{-3}\right)$} \\
\hline & & & Human consumption & Agriculture & Industry & Other uses \\
\hline \multirow{2}{*}{ German (Saxony) } & \multirow{2}{*}{ Charges for the use of water } & Quantity of abstracted surface water & 0.0150 & 0.0050 & 0.0050 & 0.0200 \\
\hline & & Quantity of abstracted groundwater & 0.0150 & 0.0250 & 0.0760 & 0.0760 \\
\hline Australia (South) & Effluent Release Charge & $\begin{array}{l}\text { Quantity of emissions to the water } \\
\text { body by impact levels }\end{array}$ & \multicolumn{4}{|c|}{$\begin{array}{l}0 \text { to } 161,289.20 \text { depending on the level of impact. } \\
\text { It is not charged by } \mathrm{m}^{3} \text {, nor by type of use. }\end{array}$} \\
\hline \multirow{2}{*}{ Belgium (Flandres) } & Groundwater Rate & Quantity of groundwater used & 0.0603 & 0.0603 & 0.0603 & 0.0603 \\
\hline & Charging of wastewater & Quantity and quality of pollution & 0.8968 & 0.8968 & 0.8968 & 0.8968 \\
\hline $\begin{array}{c}\text { Canada } \\
\text { (British Columbia) }\end{array}$ & Water Abstraction Grant Rate & Quantity of abstracted water & 12.96 per 1000 gallons & 15.01 per acre of feet per year & Varied values & Varied values \\
\hline \multirow{2}{*}{ Poland } & \multirow{2}{*}{$\begin{array}{l}\text { Charging by the abstraction of } \\
\text { water }\end{array}$} & Quantity of abstracted surface water & 0.0092 & 0.0163 & 0.0163 & 0.0163 \\
\hline & & Quantity of abstracted groundwater & 0.0163 & 0.0275 & 0.0275 & 0.0275 \\
\hline
\end{tabular}




\subsection{Water charging and the valuation of natural resources}

Environmental services are generated from ecosystem functions. The latter is identified as permanent and integrated ecological structures and processes that maintain the dynamics of ecosystems. The ecosystem functions generate direct or indirect benefits that are useful and appropriated by the human being to satisfy their needs. These functions are grouped into four primary categories: regulation function, habitat function, production function and information function (De Groot et al., 2002). When the individual prints his values on the ecosystemic functions and uses them for human purposes, they become environmental services (Andrade and Romeiro, 2009). The hydrographic basins provide services that are essential to economic development: the provision of water for multiple uses, the water filtration and purification service. However, there are costs and benefits offered by nature that are not measured efficiently by the market (Barros and Amin, 2008). Methods of valuation were created to provide an economic evaluation considering the values of direct and indirect uses, plus the option and existence values, as shown in Table 6.

Table 6. Economic Value of the Environmental Resource and the environmental services of the hydrographic basins.

\begin{tabular}{llll}
\hline \multicolumn{4}{c}{ Economic Value of Environmental Resource } \\
\hline \multicolumn{1}{c}{ Usage Value (UV) } & \multicolumn{1}{c}{ Non-Use Value (NUV) } \\
\hline Direct Use Value (DUV) & Indirect Use Value (IUV) & Option Value (OV) & Existence Value (EV) \\
\hline $\begin{array}{l}\text { Environmental goods and } \\
\text { services appropriated } \\
\text { directly from the exploration } \\
\begin{array}{l}\text { of the resource and } \\
\text { consumed today. }\end{array}\end{array}$ & $\begin{array}{l}\text { Environmental goods and } \\
\text { services that are generated } \\
\text { from ecosystem functions and } \\
\text { appropriated and consumed } \\
\text { indirectly today. }\end{array}$ & $\begin{array}{l}\text { Environmental goods and } \\
\text { services of direct and } \\
\text { indirect uses to be } \\
\text { appropriated and consumed } \\
\text { in the future }\end{array}$ & $\begin{array}{l}\text { Value not associated with } \\
\text { current or future use and } \\
\text { which reflects moral, } \\
\text { cultural, ethical or } \\
\text { altruistic issues. }\end{array}$ \\
$\begin{array}{l}\text { Examples: fisheries and } \\
\begin{array}{l}\text { aquaculture; water to drink; } \\
\text { algae as fertiliser; water for } \\
\text { non-potable uses, among } \\
\text { others. }\end{array}\end{array}$ & $\begin{array}{l}\text { Examples: water purification; } \\
\text { erosion prevention; flood } \\
\text { prevention; climate regulation, } \\
\text { among others. }\end{array}$ & $\begin{array}{l}\text { Examples: the same as } \\
\text { those of direct and indirect } \\
\text { use. }\end{array}$ & $\begin{array}{l}\text { Example: preservation of } \\
\text { emblematic species; } \\
\text { material for research, } \\
\text { among others. }\end{array}$ \\
\hline
\end{tabular}

Source: Motta (1997) and Grizzetti et al. (2016), with adaptations.

In Table 7, we describe the environmental services related to aquatic ecosystems and the hydrological cycle in a healthy watershed, distributed within the categories: provisioning services, regulatory services, cultural services and support services (MEA, 2005). Recognising the multi-functionality of water systems through the environmental services bias is fundamental to justifying the costs of their protection and restoration (Grizzetti et al., 2016).

Table 7. Categorical environmental services provided by healthy river basins.

\begin{tabular}{lll}
\hline $\begin{array}{l}\text { Category of } \\
\text { environmental services }\end{array}$ & Definition & $\begin{array}{l}\text { Examples of environmental services provided by } \\
\text { basins }\end{array}$ \\
\hline Provisioning services & Obtaining of ecosystem products & Water supply for multiple uses; fishery products \\
\hline Regulatory services & $\begin{array}{l}\text { Obtaining benefits of the regulatory } \\
\text { characteristics of ecosystem } \\
\text { processes }\end{array}$ & $\begin{array}{l}\text { Water filtration and purification; flood regulation; } \\
\text { drainage and natural irrigation; erosion and sediment } \\
\text { control; climate stabilisation }\end{array}$ \\
\hline Cultural Services & $\begin{array}{l}\text { Obtaining non-material ecosystem } \\
\text { benefits }\end{array}$ & $\begin{array}{l}\text { Recreation and tourism; aesthetic pleasure } \\
\text { (appreciation of landscapes); cultural, religious and } \\
\text { inspirational values }\end{array}$ \\
\hline Support Services & $\begin{array}{l}\text { Services required for the production } \\
\text { of all other environmental services }\end{array}$ & $\begin{array}{l}\text { The cycle of nutrients; water cycling; maintaining } \\
\text { biological diversity and aquatic genetics }\end{array}$ \\
\hline
\end{tabular}

Source: MEA (2005), Andrade (2010) and De Groot et al. (2002), with adaptations. 
De Groot et al. (2002) indicate four methods for assessing environmental resources. The first is a direct market valuation that is used when the exchange value of environmental services has an economic value in the market; it is generally applied to production, information and regulatory functions. The indirect market valuation arises when there is no explicit market for the services. It will require techniques that reveal the willingness to pay or to accept compensations such as those described in Table 8. The third method is the contingent valuation by which survey questionnaires are applied, describing hypothetical situations. Finally, group assessment is carried out through public debate.

Table 8. Description of environmental valuation techniques for indirect market valuation.

\begin{tabular}{ll}
\hline Valuation Techniques & Description \\
\hline $\begin{array}{l}\text { Contingent Value Method } \\
\text { (CVM) }\end{array}$ & $\begin{array}{l}\text { Investigates the consumer's willingness to pay (WTP) and willingness to receive } \\
\text { compensation (WTC) to keep unchanged an environmental good or service }\end{array}$ \\
\hline $\begin{array}{l}\text { Travel Cost Method } \\
\text { (TCM) }\end{array}$ & $\begin{array}{l}\text { Earn all the expenses incurred by visitors to arrive and stay in a specific recreation area to } \\
\text { enjoy the environmental resources }\end{array}$ \\
\hline $\begin{array}{l}\text { Hedonic Pricing Method } \\
\text { (HPM) }\end{array}$ & $\begin{array}{l}\text { Analyses the variation of prices of the properties according to the environmental } \\
\text { characteristics of where they are located }\end{array}$ \\
\hline $\begin{array}{l}\text { Replacement Cost Method } \\
\text { (RCM) }\end{array}$ & $\begin{array}{l}\text { Calculates the amount obtained from the expenses to restore or replace a damaged } \\
\text { environmental good or service. }\end{array}$ \\
\hline $\begin{array}{l}\text { Method of Avoided Costs } \\
\text { (MAC) }\end{array}$ & $\begin{array}{l}\text { Survey of individual expenses with a substitute or complementary products that offer } \\
\text { improvement to human well-being which was harmed by the absence of an environmental } \\
\text { service }\end{array}$ \\
\hline
\end{tabular}

Source: Andrade (2010) and De Groot et al. (2002), with adaptations.

Environmental valuation techniques are essential tools that can be used as a reference to improve the water charge. They express, in monetary terms, the approximate value of the allocation of anthropic activities to water resources in decision making (TEEB, 2010, p. 3). They also contribute to the achievement of the NWRP Law legal purpose: giving the indication of real water value, encouraging rational use and raising financial resources for the beneficiation of the river basins in which the charges were applied (Brasil, 1997).

Article 21 of the NWRP Law establishes only minimum criteria for water-charge methodologies and values. Also, Article 38, Item VI, states that it is an HBC responsibility to develop such mechanisms and values (Brasil, 1997). Based on these premises, it is possible to adjust these elements to consider the techniques of environmental valuation in decision making. However, this improvement depends on the maturity of the HBC members' experiences (NWA, 2014). Currently, Brazilian water-charge methodologies are limited to the criteria established in the NWRP Law. The NWA explains that these current methodologies aim to be clear and straightforward enough so the users can understand them. However, there is nothing to prevent future techniques from being improved and further advanced (ANA, 2014).

\section{CONCLUSIONS}

Water charges aim to stimulate the rational use of water resources and to internalise social costs not absorbed by the market. However, experience has shown that prices per cubic meter of water still tend to be very low both in international and national contexts. The methodologies include the volumetry of abstracted or consumed water associated with elements that indicate the pollution level. These elements are the biochemical oxygen demand, a parameter used in Brazil, and other chemical elements such as Phosphorus and Nitrogen, in some international scenarios.

Also, the water-charge scenarios have not considered the economic valuation of the environmental-resource perspective, either in price or methodology. The inclusion of values

Rev. Ambient. Água vol. 15 n. 4, e2531 - Taubaté 2020 
related to environmental services provided by a healthy river basin in decision-making processes can make it possible to promote the sustainable use of water resources. There are valuation techniques that can help to reveal the economic value of services with no explicit market. Further, some methods involve a public debate. These strategies can contribute to get closer to the real water value and also stimulate participative management. These initiatives can be explored in the HBCs, since they have the competence to suggest mechanisms and values of water charge. However, this improvement depends on the maturity of the HBC members' experiences.

Another obstacle found in international scenarios is the lack of transparency in the management of financial resources concerning information regarding income and its application. This makes it difficult to evaluate the effectiveness of economic instruments and to promote participatory management in making decisions. Also, the research indicates how the techniques of environmental valuation could improve the water charge methodologies. For future research, we suggest the application of the valuation techniques and methods in a river basin where there is an HBC to verify the advantages and obstacles in practice.

\section{REFERENCES}

ANA (Brasil). Conjuntura dos recursos hídricos: informe 2016. Brasília, 2016.

ANA (Brasil). Cadernos de capacitação em recursos hídricos: cobrança pelo uso de recursos hídricos. v. 7. Brasília, 2014.

ANA (Brasil). Cobrança pelo uso de recursos hídricos. Available at: https://www.ana.gov.br/gestao-da-agua/cobranca. Acess: 9 May 2018.

ANDRADE, D. C.; FASIABEN, M. DO C. R. A utilização dos instrumentos de política ambiental para a preservação do meio ambiente: o caso dos pagamentos por serviços ecossistêmicos. Revista Economia Ensaios, v. 24, n. 1, 2009.

ANDRADE, D. C.; ROMEIRO, A. R. Capital natural, serviços ecossistêmicos e sistema econômico: ruma a uma "economia dos ecossistemas". Texto para discussão. Campinas: IE/UNICAMP, 2009. p. 159, 2-23. Available at: www.eco.unicamp.br/docprod/downarq.php?id=1789\&tp=a. Access: 27 Feb. 2018.

ANDRADE, D. C. Modelagem e valoração de serviços ecossistêmicos: uma contribuição da economia ecológica. 2010. Tese (Doutorado em Desenvolvimento Econômico) - Instituto de Economia da UNICAMP, Campinas, SP, 2010.

ANEEL (Brasil). Resumo total anual pago pelas Usinas ano de 2017. 2017. Available at: http://www2.aneel.gov.br/aplicacoes/cmpf/gerencial/. Access: 9 May 2018.

ARIMURA, T. H.; HIBIKI, A.; KATAYAMA, H. Is a voluntary approach an effective environmental policy instrument? A case for environmental management systems. Journal of Environmental Economics and Management, v. 55, p. 281-295, 2008. http://dx.doi.org/10.1016/j.jeem.2007.09.002

BARROS, F. G. N.; AMIN, M. M. Água: um bem econômico de valor para o Brasil e o mundo. Revista Brasileira de Gestão e Desenvolvimento Regional, v. 4, n. 1, p. 75-108, 2008.

BEGOSSI, A.; MAY, P. H.; LOPES, P. F.; OLIVEIRA, L. E. C.; VINHA, V. DA; SILVANO, R. A. M. Compensation for environmental services from artisanal fisheries in SE Brazil: Policy and technical strategies. Ecological Economics, v. 71, p. 25-32, 2011. https://dx.doi.org/10.1016/j.ecolecon.2011.09.008 
BERRETA, M. DOS S. R.; LAURENT, F.; BASSO, L. A. Os princípios e fundamentos da legislação das águas na França. Boletim Gaúcho de Geografia, v. 39, p. 13-24, 2012.

BERGQUIST, A. K.; SÖDERHOLM, K.; KINNERYD, H.; LINDMARK, M.; SÖDERHOLM, P. Command-and-control revisited: Environmental compliance and technological change in Swedish industry 1970-1990. Ecological Economics, v. 85, p. 6-19, 2013. http://dx.doi.org/10.1016/j.ecolecon.2012.10.007

BOLSON, S. H.; HAONAT, A. I. A governança da água, a vulnerabilidade hídrica e os impactos das mudanças climáticas no Brasil. Veredas do Direito, v. 13, n. 25, p. 223 248. 2016. http://dx.doi.org/10.18623/rvd.v13i25.575

BRAGA, B. P. F.; FLECHA, R.; PENA, D. S.; KELMAN, J. Pacto federativo e gestão de águas. Estudos Avançados, v. 63, n. 22, p. 17-42, 2008. http://dx.doi.org/10.1590/S010340142008000200003

BRASIL. Presidência da República. Constituição da República Federativa do Brasil de 1988. Diário Oficial [da] União: seção 1, Brasília, DF, n. 191-A, p. 1-32, 05 out. 1988.

BRASIL. Presidência da República. Lei n. 9.433, de 9 de janeiro de 1997. Institui a Política Nacional de Recursos Hídricos, cria o Sistema Nacional de Gerenciamento de Recursos Hídricos, regulamenta o inciso XIX do art. 21 da Constituição Federal, e altera o art. $1^{\circ}$ da Lei $n^{\circ}$ 8.001, de 13 de março de 1990, que modificou a Lei n ${ }^{\circ} 7.990$, de 28 de dezembro de 1989. Diário Oficial [da] União: seção 1, Brasília, DF, 09 jan. 1997.

BRASIL. Presidência da República. Lei n. 9.648, de 27 de maio de 1998. Altera dispositivos das Leis no 3.890-A, de 25 de abril de 1961, no 8.666, de 21 de junho de 1993, no 8.987, de 13 de fevereiro de 1995, no 9.074, de 7 de julho de 1995, no 9.427, de 26 de dezembro de 1996, e autoriza o Poder Executivo a promover a reestruturação da Centrais Elétricas Brasileiras - ELETROBRÁS e de suas subsidiárias e dá outras providências. Diário Oficial [da] União: seção 1, Brasília, DF, 28 maio 1998.

CBH-VERDE GRANDE. Deliberação no. 50/2015. Estabelece mecanismos e sugere valores de cobrança pelo uso de recursos hídricos na bacia hidrográfica do rio Verde Grande. 2015. Available

at: http://arquivos.ana.gov.br/institucional/sag/CobrancaUso/Legislacao/Deliberacao_CBH -VG_n_50-2015.pdf. Access: 20 Nov. 2017.

CBH-PARANAÍBA. Deliberação $\mathbf{n}^{\mathbf{0}}$. 61/2016. Dispõe sobre mecanismos e valores de cobrança pelo uso de recursos hídricos de domínio da União, propõe as acumulações, derivações, captações e lançamentos de pouca expressão na bacia hidrográfica do rio Paranaíba e dá outras providências. 2016. Available at: http://arquivos.ana.gov.br/institucional/sag/CobrancaUso/Cobranca/Deliberacao_CBH_ Paranaiba_n_61_16.pdf. Access: 20 Nov. 2017.

DE GROOT, R. S.; WILSON, M. A.; BOUMANS, R. M. J. A typology for the classification, description and valuation of ecosystem functions, goods and services. Ecological Economics, v. 41, p. 393-408, 2002. https://doi.org/10.1016/S0921-8009(02)00089-7

DEMAJOROVIC, J.; CARUSO, C.; JACOBI, P. R. Cobrança do uso da água e comportamento dos usuários industriais na bacia hidrográfica do Piracicaba, Capivari e Jundiaí. Revista de Administração Pública, v. 49, n. 5, p. 1193-1214, 2015. http://dx.doi.org/10.1590/0034-7612137792 
FARIAS, C.; DAMACENA, F. Meio ambiente e economia: uma perspectiva para além dos instrumentos de comando. Revista de Direito Econômico e Socioambiental, v. 8, n. 1, p. 148-181, 2017. http://dx.doi.org/10.7213/rev.dir.econ.soc.v8i1.9696

FINKLER, N. R.; MENDES, L. A.; BORTOLIN, T. A.; SCHNEIDER, V. E. Cobrança pelo uso da água no Brasil: uma revisão metodológica. Revista Desenvolvimento e Meio Ambiente, v. 33, p. 33-49, 2015. http://dx.doi.org/10.5380/dma.v33i0.36413

FOSTER, S.; CHILTON, J.; NIJSTEN, G.; RICHTS, A. Groundwater - a global focus on the "local resource". Current opinion in environmental sustainability, v. 5, p. 685-695, 2013. https://doi.org/10.1016/j.cosust.2013.10.010

GODOY, A. M. G. A abordagem neoclássica sobre a cobrança pelo uso da água dá conta da realidade? Revista Estudos do CEPE, v. 34, p. 202-230, 2011. http://dx.doi.org/10.17058/cepe.v0i34.1678

GOMES, C. S.; ROQUETTI, D. R.; PULICE, S. M. P.; MORETTO, E. M. Usinas hidrelétricas e desenvolvimento municipal: o caso das usinas hidrelétricas do complexo PelotasUruguai. Revista de Gestão Ambiental e Sustentabilidade, v. 6, n. 2, 2017. https://dx.doi.org/10.5585/geas.v6i2.931

GÓMEZ-BAGGETHUN, E.; MURADIAN, R. In markets we trust? Setting the boundaries of Market-Based Instruments in ecosystem services governance. Ecological Economics, v. 117, p. 217-224, 2015. http://dx.doi.org/10.1016/j.ecolecon.2015.03.016

GRIZZETTI, B.; LANZANOVA, D.; LIQUETE, C.; REYNAUD, A.; CARDOSO, A. C. Assessing water ecosystem services for water resource management. Environmental Science \& Policy, v. 61, p. 194-203, 2016. https://doi.org/10.1016/j.envsci.2016.04.008

GVCES. Estudo de aplicação de instrumentos econômicos à gestão de recursos hídricos em situações críticas: sumário para tomadores de decisão. São Paulo, 2017. Available at: http://gvces.com.br/estudo-de-aplicacao-de-instrumentos-economicos-a-gestao-dosrecursos-hidricos-em-situacoes-criticas?locale=pt-br. Access: 28 Feb. 2018.

HARADA, K. Direito Financeiro e Tributário. 25. ed. São Paulo: Atlas, 2016.

JOHNSSON, R. M. F. La nouvelle politique de l'eau au Brésil: forces et enjeux d'une transformation vers une gestion intégrée. Tiers-Monde, v. 42, n. 166, p. 403-425, 2001. https://doi.org/10.3406/tiers.2001.1501

LANNA, A. E. L. Hidroeconomia. In: REBOUÇAS, A. Da C.; BRAGA, B.; TUNDISI, J. G. (Orgs.). Águas doces no Brasil: capital ecológico, uso e conservação. 2. ed. São Paulo: Escrituras, 2002. cap. 16. p. 531-562.

LEITE, F. do R. V. D. As participações governamentais na indústria do petróleo sob a perspectiva do estado-membro: importância econômica, natureza jurídica e possibilidade de fiscalização direta. Revista de Direito GV, v. 5, n. 2, p. 527-548, 2009. http://dx.doi.org/10.1590/S1808-24322009000200015

LIAO, Z. Environmental policy instruments, environmental innovation and the reputation of enterprises. Journal of Cleaner Production, v. 171, p. 1111-1117, 2018. https://doi.org/10.1016/j.jclepro.2017.10.126

MATTHEIß, V.; STROSSER, P.; RODRÍGUEZ, J. M. C. Notes on financing water resources management:Background report for the OECD Expert Meeting on Water Economics and Financing. Paris: ACTeon, 2010. Available at: https://www.oecd.org/env/resources/45058008.pdf. Access: Jun. 2018. 
MEDEIROS, J. B.; TOMASI, C. Redação de artigos científicos: métodos de realização, seleção de periódicos, publicação. São Paulo: Atlas, 2016.

MILlAN, P. Cobrança pelo uso dos recursos hídricos. Revista da Faculdade de Direito da Universidade de São Paulo, v. 103, p. 537-560, 2008.

MILARÉ, E. Direito do Ambiente: a gestão ambiental em foco: doutrina, jurisprudência, glossário. 7. ed. São Paulo: Revista dos Tribunais, 2011.

MEA. Ecosystems and their services. In: MEA. Ecosystem and Human Well-being: a framework for assessment. 2005. cap. 2. p. 49-70. Available at: https://www.millenniumassessment.org/documents/document.300.aspx.pdf. Access: 27 Feb. 2018.

MOTTA, R. S. Uso de instrumentos econômicos na gestão ambiental. Rio de Janeiro: IPEA, 2000. Available at: https://www.cepal.org/ilpes/noticias/paginas/1/35691/JA_Instr_Econ_Gestion_Ambient al_R_Seroa_da_Motta.pdf. Access: 2 Jul. 2017.

MOTTA, R. S. Manual para a valoração econômica de recursos ambientais. Rio de Janeiro: IPEA/MMA/PNUD/CNPQ, $1997 . \quad$ Available at: http://www.terrabrasilis.org.br/ecotecadigital/pdf/manual-para-valoracao-economica-derecursos-ambientais.pdf. Access: 12 Jun. 2018.

NASCIMENTO, L. M. do; XAVIER, Y. M. de A.; GUIMARÃES, P. B. V. A cobrança da água como mecanismo de correção de externalidades ambientais negativas. In: XAVIER, Y. M. de A.; GUIMARÃES, P. B. V.; SILVA, M. dos R. F. (Orgs.). Recursos hídricos e atividade econômica na perspectiva jurídica do desenvolvimento sustentável. Fortaleza: Fundação Konrad Adenauer Stiftung, 2010. cap. 2.

NUSDEO, A. M. de O. O uso de instrumentos econômicos nas normas de proteção ambiental. Revista da Faculdade de Direito da Universidade de São Paulo, v. 101, p. 357-378, 2006. https://doi.org/10.11606/issn.2318-8235.v101i0p357-378

OECD. Database on policy instruments for the environment. 2016. Available at: https://pinedatabase.oecd.org/Query_2.aspx?QryCtx=3\&isid=a1fc4325-5877-4a77b984-ab11bdfcf12a. Access: 19 Mar. 2018.

OECD. Water pricing in OECD countries: State of play. In: OECD. Pricing water resources and water and sanitation services. Paris: OECD Publishing, 2010. cap. 2. p. 33-62. http://dx.doi.org/10.1787/9789264083608-5-en

OECD. Cobranças de água no Brasil: direções a seguir. Paris: Éditions OECD, 2017. https://doi.org/10.1787/9789264286214-pt

PAUlsen, L. Curso de Direito Tributário Completo. 4. ed. Porto Alegre: Livraria do Advogado, 2012.

PRODANOV, C. C.; FREITAS, E. C. de. Metodologia do trabalho científico: métodos e técnicas da pesquisa e do trabalho acadêmico. 2. ed. Novo Hamburgo: Feevale, 2013.

ROGERS, P.; SILVA, R. de; BHATIA, R. Water is an economic good: how to use prices to promote equity, efficiency, and sustainability. Water Policy, v. 4, p. 1-17, 2002. https://dx.doi.org/10.1016/S1366-7017(02)00004-1 
SANTIN, J. R.; GOELLNER, E. A gestão dos recursos hídricos e a cobrança pelo seu uso.

Sequência, v. 67, p. 199-221, 2013. http://dx.doi.org/10.5007/2177-7055.2013v34n67p199

SANTOS, L. M. dos; PORTO, A. J. M.; SAMPAIO, R. S. da R. Direitos de propriedade e instrumentos econômicos de regulação ambiental: uma análise das atribuições implícitas. Revista Brasileira de Políticas Públicas, v. 7, n. 2, p. 98-121, 2017. http://dx.doi.org/10.5102/rbpp.v7i2.4633

SCHMIDT, J. J.; MATTHEWS, N. Global water governance: an overview. In: SCHMIDT, J. J.; MATTHEWS, N. Global challenges in water governance: environments, economies, societies. Zurique: Palgrave MacMillan Springer Nature, 2017. https://dx.doi.org/10.1007/978-3-319-61503-5

STERNER, T.; ROBINSON, E. J. Z. Selection and design of environmental policy instruments. In: DASGUPTA, P.; PATTANAYAK, S. K.; SMITH, V. K. (eds.). Handbook of $\begin{array}{lll}\text { Environmental } & \text { Economics. } & \\ & & \end{array}$ https://doi.org/10.1016/bs.hesenv.2018.08.002

TEEB. A Economia dos Ecossistemas e da Biodiversidade: integrando a economia da natureza. Uma síntese da abordagem, conclusões e recomendações do TEEB. 2010. Available at: http://doc.teebweb.org/wpcontent/uploads/Study\%20and\%20Reports/Reports/Synthesis\%20report/TEEB_SintesePortugues.pdf. Access: 12 Jun. 2018.

THEODORO, H. D.; NASCIMENTO, N. DE O.; HELLER, L. Análise comparativa da gestão institucional de recursos hídricos via estudo de casos internacionais. REGA, v. 13, n. 2, p. 110-128, 2016. https://dx.doi.org/10.21168/rega.v13n2.p110-128

VATN, A. Markets in environmental governance. From theory to practice. Ecological Economics, v. 117, p. 225-233, 2015. http://dx.doi.org/10.1016/j.ecolecon.2014.07.017

VERA, L. H. A.; MONTENEGRO, S. M. G. de L.; SILVA, S. R. da. Performance of water usage charge in the Nation's domain as a water resource management tool in the São Francisco River basin. Revista Brasileira de Recursos Hídricos, v. 22, 2017. http://dx.doi.org/10.1590/2318-0331.011715171

YOUNG, C. E. F.; BAKKER, L. B. Instrumentos econômicos e pagamentos por serviços ambientais no Brasil. In: FOREST TRENDS. Incentivos econômicos para serviços ecossistêmicos no Brasil. Rio de Janeiro, 2015. p. 33-56. 